\title{
PERFORMANCE AND PHYSIOLOGICAL RESPONSES OF BROILER CHICKENS TO DIETARY COMBINATION OF YEAST AND MEDICAL PLANTS.
}
S. S. M. Beski
S. A. M'Sadeq
S. M. Hussein
A. L. Mahmod
Assist. Prof.
Assist. Prof.
Lecturer
Researcher

Dept. Anim. Prod, Coll. Agric. Eng. Sci. University of Duhok, Iraq

e-mail: sleman.mohammed@uod.ac

\section{ABSTRACT}

This feeding trial was conducted to investigate the effect of medical plants and yeast cell wall on the performance and subsequent physiology of broiler chickens. A total of 200 d-old Ross 308 broiler chicks were randomly allocated to 5 treatments that were replicated 4 times of 10 birds. The first treatment was the control while the remaining four treatments were supplemented with one of these mixtures (peppermint and Chamomile; peppermint powder and yeast cell wall; chamomile powder and yeast cell wall; peppermint, yeast cell wall and chamomile powder). Throughout the experimental period, feed intake was almost not affected by dietary treatments. At days 24 and 35 of age, birds on diets containing mixtures of herbal plants or herbal plants with yeast gained more weight than the control group. Feed conversion ratio of the $24 \mathrm{~d}$-old broilers was significantly improved by the combination of herbal plants and its combination with yeast. However, when assessed over the 35 d experimental period, it was almost same among all experimental units. The relative weight of visceral organs and bursal morphology were not affected by dietary treatments. Significantly lower serum cholesterol and longer jejunum villi were detected in birds that were offered diets supplemented with mixture of herbal plants alone or its combination with yeast.

Key words: medical plants, yeast cell wall, broiler performance

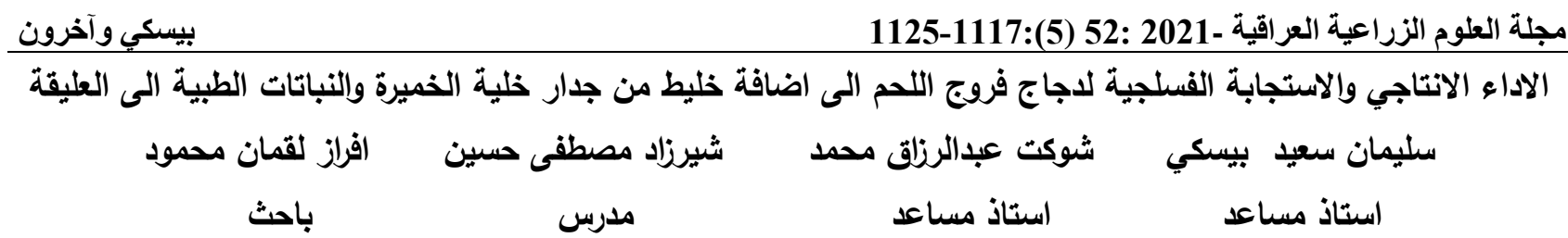

أجريت تجرية التخذية هذه للتحقق من تأثير النباتات الطبية وجدار خلية الخميرة على أداء وفسيولوجيا اللدجاج اللحم. وزعت عشوائيا 200 فرخة عمر يوم من كتكوت اللحم روس 308 على 5 معاملات تم تكرارها 4 مرات لعشرة طيور. كان العلاج الأول هو التحكم بينما تم تكميل المعاملات الأربعة المتبقية بأحد هذه الخلائط (النعنـاع والبابونج ، ومسحوق النعناع وجدار خليـة الخميرة ، ومسـوق البابونج وجدار خليـة الخميرة ، والنعنـاع ، وجدار خليـة الخميرة ، ومسحوق البابونج). طوال فترة التجربة ، لم يتأثر تتاول العلف تقريبًا بالمعاملات الغذائية. في اليومين 24 و 35 من العمر ، اكتسبث الطيور التي تتبع نظامًا غذائيًا يحتوي على خليط من النباتات العشبية أو النباتات العشبية مـع الخميرة وزنًا أكبر من المجموعة الضـابطة. تم تحسبن معدل التحويل الغذائي للفروج البالغة من العمر 24 د بشكل ملحوظ من خلال الجمع بين التباتات العثبية ودمجها مع الخميرة. ومع ذلك ، عند التقيبم على مدار فترة تجريبية تبلع 35 يومًا ، كان متماتثلا تقريبًا بين جميع الوحدات التجريبية. لم يتأثر الوزن النسبي للأعضاء مورفولوجيا بالمعاملات الغذائية. تم اكتثاف انخفاض كبير في نسبة الكوليسترول في الدم وزيـادة طول الصائم الزغبي في الطيور التي قدمت وجبات مكملة بمزيج من النباتات العثبية وحدها أو مزيج من الخميرة. الكلمات المفتاحية: النباتات الطبية ، جدار خلية الخميرة ، أداء دجاج التسمين. 


\section{INTRODUCTION}

It's well-known that broiler production is continuously facing the nutritional and health threating problems due to the nature of its rearing. Therefore, to eliminate the stress of the intensive rearing practices and improve their well-being, broilers are continuously fortified with growth promoters and stress eliminating feeding products. Antibiotics were the most effective growth promoters that have been used in broiler nutrition. However their extensive usage has developed some health problems to the society due to its residual in the consuming poultry products and the bacterial resistance to it so far $(4,21)$. Therefore, the nutritional strategies to improve the growth performance of broilers while reducing its mortality via antibiotics as growth promoters have been changed after being under severe criticism in poultry nutrition $(10$, 16). Finding the possible natural growth promoters is becoming a must after the banning or the restriction of the use of artificial antibiotics in poultry nutrition (5). Prebiotic and medical plants have gained the interest to be used in poultry nutrition as possible alternatives to antibiotics due to their content of biological active compounds. Recently, prebiotics have been broadly supplemented into broiler diets. Prebiotics are non-digestible feed compounds; however it's the preferable substrates that are utilized by hosts' intestinal microbiota conferring a health benefit (8). It beneficially affects the host by stimulating the growth and the activity of bacteria in the intestinal tract, consequently improving gut health and hosts' intestinal microbial balance. In addition dietary prebiotics have been shown to enhance digestive functionality of the poultry gastrointestinal tract (20) and positively affect animal performance by increasing body weight $(7,27)$ and improving feed efficiency (26).

The use of medical plants as feed additives, which comprise a wide variety of herbs, has recently gained increasing interest potential alternative natural growth promoters. Among them is Chamomile flowers (Matericaria chamomilla $L$ ), that have anti-inflammatory, antiseptic, carminative, diaphoretic, sedative properties due to its content of several numerous health benefiting phytonutrients including essential oil with azulene, bisabolo, flavonoid, glycosides and fatty acids $(18,23)$. Dietary chamomile positively affected the growth performance of broiler chickens (1). Peppermint (Mentha piperita L.) has also been frequently used in herbal medicine as an immune system stimulator. In addition it has antimicrobial and antioxidant and appetite enhancing characteristics (28). The benefit of dietary peppermint has been confirmed in broiler nutrition (22). This study was aimed to address the effect of the dietary combination of yeast, chamomile and peppermint on the growth performance, physiological responses and the intestinal histomorphology of broiler chickens.

\section{MATERIALS AND METHODS}

This experiment was approved by the Animal Ethic committee of the College of Agricultural Engineering Sciences, University of Duhok (Approval No: AEC 120120203). Health and animal husbandry practices complied with the Code of Practice for the Use of Animals for scientific purposes issued by the mentioned animal ethic committee.

\section{Experimental design and bird management}

In a completely randomized design, a total of 200 d-old Ross 308 broiler chicks were assigned to 5 treatments of 4 replicates of 10 birds per a replicate. Treatments were control, $\mathrm{P}+\mathrm{CH}$ (basal diet supplemented with $5 \mathrm{~g} / \mathrm{kg}$ of each peppermint powder and Chamomile powder), $\mathrm{P}+\mathrm{Y}$ (basal diet supplemented with $5 \mathrm{~g} / \mathrm{kg}$ of each peppermint powder and a part of Yeast Cell Wall (Catch Myco)), $\mathrm{CH}+\mathrm{Y}$ (basal diet supplemented with $5 \mathrm{gm} / \mathrm{kg}$ of each chamomile powder Yeast Cell Wall (Catch Myco)), $\mathrm{P}+\mathrm{Y}+\mathrm{CH}$ (basal diet supplemented with $5 \mathrm{gm} / \mathrm{kg}$ of each peppermint powder, Yeast Cell Wall and chamomile powder). The main active compounds in peppermint and chamomile are presented in Table 1. All birds were vaccinated against infectious bronchitis and Newcastle diseases. Chicks were reared in floor pens $(100 \times 100 \mathrm{~cm})$ bedded with wood shaving Three phases of feeding were adopted, a starter diet from 1 to $10 \mathrm{~d}$, grower diets from 11 to $24 \mathrm{~d}$, and finisher diets from 25 to $35 \mathrm{~d}$. All diets were formulated to meet the requirements for Ross 308 broiler chickens (Tables 2). The room temperature was gradually decreased from $33{ }^{\circ} \mathrm{C}$ on $\mathrm{d} 1$ to 24 
${ }^{\circ} \mathrm{C} \pm 1{ }^{\circ} \mathrm{C}$ at 35 d. Eighteen hours of lighting were provided per $\mathrm{d}$ throughout the duration of the experiment, apart from d 1 to 7 when 23 hours of lighting were provided. Feed and water were provided ad libitum. On d 10, 24 and 35 , the feed leftover and birds were weighed to measure the body weight, weight gain, feed intake and feed conversion ratio. Mortalities were recorded as they occurred, and feed per gain values were corrected for mortality.

Table 1. The main active compounds of peppermint and Chamomile.

\begin{tabular}{|c|c|c|c|c|c|c|c|c|}
\hline \multirow{3}{*}{$\begin{array}{l}\text { Initial } \\
\text { concentration }\end{array}$} & \multicolumn{4}{|c|}{ DPPH Analysis (Inhibition\%) } & \multicolumn{4}{|c|}{ CUPRAC Analysis (Inhibition\%) } \\
\hline & \multicolumn{2}{|c|}{ Water Extract } & \multicolumn{2}{|c|}{ Methanol Extract } & \multicolumn{2}{|c|}{ Water Extract } & \multicolumn{2}{|c|}{ Methanol Extract } \\
\hline & $\mathbf{P}$ & $\mathrm{CH}$ & $\mathbf{P}$ & $\mathbf{C H}$ & $\mathbf{P}$ & $\mathbf{C H}$ & $\mathbf{P}$ & CH \\
\hline $1000 \mu \mathrm{g} / \mathrm{ml}$ & 81.03 & 84,090 & 85.19 & 88,171 & 3.74 & 1,107 & 3.63 & 1,114 \\
\hline $500 \mu \mathrm{g} / \mathrm{ml}$ & 64.78 & 70,529 & 74.78 & 73,109 & 2.32 & $\mathbf{0 , 7 3 5}$ & 2.31 & 0,761 \\
\hline $250 \mu \mathrm{g} / \mathrm{ml}$ & 47.75 & 65,221 & 56.75 & 67,201 & 1.26 & 0,418 & 1.25 & 0,418 \\
\hline $125 \mu \mathrm{g} / \mathrm{ml}$ & 34.57 & 40,964 & 42.57 & 48,032 & 0.81 & 0,266 & 0.80 & 0,267 \\
\hline $62.5 \mu \mathrm{g} / \mathrm{ml}$ & 27.85 & 31,628 & 31.85 & 32,645 & 0.54 & 0,191 & 0.54 & 0,19 \\
\hline $\begin{array}{l}\text { Content } \pm \text { SD } \\
\text { Inhibition \% } \pm \\
\text { SD }\end{array}$ & $\begin{array}{c}\text { Medical } \\
\text { Plant }\end{array}$ & Water Extract & $\begin{array}{l}\text { Methanol } \\
\text { Extract }\end{array}$ & & & & & \\
\hline Total Phenolic & $\mathbf{P}$ & $102.671 \pm 0.98$ & $90.879 \pm 1.02$ & & & & & \\
\hline & $\mathbf{C H}$ & $42,120 \pm 0.62$ & $26,377 \pm 1.05$ & & & & & \\
\hline Total flavonoid & $\begin{array}{c}\mathbf{P} \\
\mathbf{C H} \\
\mathbf{P}\end{array}$ & $\begin{array}{c}21.464 \pm 0.36 \\
4,193 \pm 0.02 \\
90.28 \pm 0.36\end{array}$ & $\begin{array}{c}26.023 \pm 0.61 \\
6,193 \pm 1.08 \\
94.16 \pm 0.25\end{array}$ & & & & & \\
\hline BChE & $\begin{array}{c}\mathbf{C H} \\
\mathbf{P} \\
\mathbf{C H}\end{array}$ & $\begin{array}{c}49.35 \pm 1.21 \\
86.06 \pm 1.12 \\
60.86 \pm 0.14\end{array}$ & $\begin{array}{c}32.16 \pm 1.05 \\
88.55 \pm 0.19 \\
56.50 \pm 0.92\end{array}$ & & & & & \\
\hline
\end{tabular}

*DPPH (diphenyl-2-picrylhydrazil Inhibition), CUPRAC (CUPric Reducing Antioxidant Capacity), (AChE) Acetylcolinesterase, $(\mathrm{BChE})$ Butyrylcholinesterase. $\mathrm{P}=$ Peppermint, $\mathrm{CH}=$ Chamomile. ${ }^{*}$ Own analysis

\section{Sample collection}

On d 24, two birds per pen were randomly selected, weighed, and euthanized by cervical dislocation. The abdominal cavity was opened and visceral organs removed. The weights of immune related organs (liver, spleen and bursa of Fabricius) heart and gizzards were recorded and calculated as mass per unit of live bod yweight ( $\mathrm{g} / 100$ of live body weight). Blood samples were collected and serum was harvested for serum biochemistry, enzymes and analyses. Approximately $1 \mathrm{~cm}$ of the jejunum and the whole bursa were collected for morphometric analysis. Tissue samples were opened and flushed clean with normal saline and were fixed in $10 \%$ buffered formalin for 24 hours. Formalin was subsequently replaced by $70 \%$ ethanol for long-term storage.

\section{Serum biochemical parameters}

Blood samples (approximately $5 \mathrm{ml}$ ) were collected from the jugular vein into nonheparinized tubes. Subsequently, serum was harvested after centrifuging the blood for 15 min and stored in the refrigerator for analyses. Serum biochemical parameters including total protein, albumin, globulin, cholesterol, alanine transaminase (ALT) and aspartate aminotransferase (AST) were determined using an automatic COBAS INTEGRA400 plus analyzer (Cedex Bio HT Analyzer).

\section{Jejunum and bursa histology}

Tissue samples were collected and fixed in $10 \%$ neutral buffered formalin for histomorphological analysis. Samples were embedded in paraffin wax, sectioned and stained with haematoxylin and eosin. Sample sections were captured at $10 \times$ magnification using a digital camera under microscope (Dino-Eye-Microscope Eye-piece Camera) and morphometric indices were determined by Dino-eye program. Images were digitized and the villus height (from the tip of the villus to the villus/crypt junction), crypt depth (from the villus/crypt junction to the muscular junction) and jejunal muscular thickness were measured in 10 well-orientated villi for each jejunal section. The apparent villus surface area was also calculated using the formula: $\{[($ villus tip + villus base $) / 2] \times$ villus height $\}$ (13).The length and width of 10 Bursal follicles and its area were measured by the same technique. 
Table 2. Ingredients and nutrient composition of starter, grower and finisher diets as percentage.

\begin{tabular}{|c|c|c|c|}
\hline Ingredients kg & Starter & Grower & Finisher \\
\hline Corn & 53.06 & 56.9 & 61.74 \\
\hline Soybean meal & 31.48 & 32.89 & 28.23 \\
\hline Fish meal & 4 & - & - \\
\hline Vegetable oil & 3 & 4.48 & 4.57 \\
\hline Limestone & 2 & 1.39 & 1.35 \\
\hline Dical Phos & 2.72 & 0.95 & 0.82 \\
\hline Salt & 0.11 & 0.19 & 0.08 \\
\hline D,L-methionine & 0.38 & 0.32 & 0.24 \\
\hline L-lysine HCl & 0.5 & 0.26 & 0.21 \\
\hline L-threonine & 0.25 & 0.13 & 0.09 \\
\hline Broiler premix & 2.5 & 2.5 & 2.5 \\
\hline \multicolumn{4}{|l|}{ Nutrient composition } \\
\hline ME $($ kcal/kg) & 3000 & 3150 & 3200 \\
\hline Crude protein & 23 & 21 & 19.16 \\
\hline Crude fiber & 2.25 & 2.38 & 2.33 \\
\hline Digestible Arginine & 1.29 & 1.14 & 0.99 \\
\hline Digestible Lysine & 1.29 & 1.14 & 0.99 \\
\hline Digestible Meth+Cyst & 0.87 & 0.84 & 0.73 \\
\hline Digestible Tryptophan & 0.226 & 0.24 & 0.21 \\
\hline Digestible Isoleucine & 0.87 & 0.81 & 0.73 \\
\hline Digestible Threonine & 0.82 & 0.73 & 0.63 \\
\hline Digestible Valine & 0.99 & 0.92 & 0.83 \\
\hline Calcium & 1.60 & 0.9 & 0.85 \\
\hline Available Phosphorus & 0.844 & 0.450 & 0.42 \\
\hline Sodium & 0.16 & 0.160 & 0.16 \\
\hline Chloride & 0.35 & 0.312 & 0.23 \\
\hline Linoleic & 2.18 & 2.64 & 2.73 \\
\hline
\end{tabular}

\section{Statistical analysis of data}

In a complete randomize analysis, all collected data were analyzed by one way ANOVA of SAS 2013. Differences between mean values were determined using Duncan's multiple range test.

\section{RESULTS AND DISCUSSION}

\section{Growth performance}

At day 10 of birds' age, Feed intake was not affected by dietary treatments except for those on diets containing a mixture of Peppermint + Yeast cell wll that were consumed less feed than other experimental groups (Table 3). However, feed consumption was almost same in all experimental groups in the subsequent grower and finisher periods. Body weight gain of broilers was not affected by treatments in the first 10 days of their age. However, over the 24 days of broilers' age, it significantly increased in all experimental groups compared to the control group. When assessed over the 35 days experimental period, body weight gain was improved in all additive supplemented groups compared to the control groups. Feed conversion ratio was not affected by dietary treatments in the first 10 days of birds' age. However at day 24, it significantly improved by dietary yeast, peppermint and chamomile supplemented birds. Feed conversion ratio of all groups was almost same over 35 days of broilers age. The results of the current study demonstrated that broiler performance was improved by dietary herbal plants and yeast. The positive effect of feeding herbal plant and its by-products on the performance and the productivity of broilers has been confirmed. This could be attributed to the presence of various active compounds that could enhance feed consumption, improve the secretion and activity of digestive enzymes and increase the intestinal digestion and absorption of nutrients (19). In addition, its ability to eliminate the pathogenic bacteria in the gut, medical plants may decrease the degradation of protein and amino acid and thus improve the absorption and accretion in the body and improve the carcass weight (17). Administration of dietary prebiotics has been demonstrated to promote populations of beneficial bacteria and decrease populations of pathogens in the GI tract in poultry (24), and prebiotics have been suggested as potential alternatives to AGP because of their ability to improve growth performance similarly to antibiotics (11). This 
was in line with finding of (16) when different levels of chamomile were fed to broilers. Abdel-Wareth et al. (2) reported that broilers body weight and weight gain were significantly increased by dietary peppermint. Furthermore, $(9,21)$ found that incorporation of peppermint to the diet significantly improved the body weight, weight gain and feed conversion ratio of broiler chickens. Froebel et al. (7) found that dietary administration of prebiotics had a positive effect on the body weight and weight gain of broilers.

\section{Relative weight of internal organs}

In general the relative weight of the visceral organs was not affected by dietary treatments. However, the relative weight of all internal organs was higher in birds that were offered diets containing the mixture of peppermint and chamomile than other experimental groups (Table 4). The effect of medical plants and yeast cell wall on the internal organs may be functional not physical

Table 3. Effect of different treatments on the broiler performance

\begin{tabular}{|c|c|c|c|c|c|c|c|}
\hline Period Treatments $^{*}$ & Control & $\mathbf{P}+\mathrm{CH}$ & $\mathbf{P}+\mathbf{Y}$ & $\mathbf{C H}+\mathrm{Y}$ & $\mathbf{P}+\mathrm{Y}+\mathrm{CH}$ & $\begin{array}{l}\text { Pooled } \\
\text { SEM }\end{array}$ & P-Value \\
\hline \multicolumn{8}{|l|}{ Feed intake (g/bird) } \\
\hline 1-10d & $295.5^{a}$ & $297.0^{a}$ & $259.0^{b}$ & $291.5^{\mathrm{a}}$ & $295.5^{\mathrm{a}}$ & 4.168 & 0.003 \\
\hline $1-24 d$ & 1369.0 & 1385.0 & 1367.5 & 1380.8 & 1337.3 & 8.204 & 0.407 \\
\hline $1-35 d$ & 2794.3 & 2935.5 & 2967.5 & 2935.8 & 2903.3 & 25.159 & 0.224 \\
\hline \multicolumn{8}{|c|}{ Body weight gain (g/bird) } \\
\hline $1-10 d$ & 247.8 & 255.8 & 228.3 & 251.5 & 244.5 & 3.968 & 0.230 \\
\hline $1-24 d$ & $982.3^{c}$ & $1074.0^{\mathrm{ab}}$ & $1118.5^{\mathrm{a}}$ & $1105.0^{\mathrm{a}}$ & $1037.8^{\text {bc }}$ & 13.511 & 0.001 \\
\hline $1-35 d$ & 1894.8 & 1985.5 & 2013.5 & 1988.8 & 1967.8 & 17.001 & 0.230 \\
\hline \multicolumn{8}{|c|}{ Feed conversion ratio (FCR) } \\
\hline 1-10d & 1.199 & 1.165 & 1.138 & 1.161 & 1.211 & 0.013 & 0.440 \\
\hline $1-24 d$ & $1.394^{\mathrm{a}}$ & $1.290^{\mathrm{b}}$ & $1.223^{c}$ & $1.252^{\mathrm{bc}}$ & $1.289^{b}$ & 0.015 & $<.0001$ \\
\hline $1-35 d$ & 1.475 & 1.479 & 1.474 & 1.476 & 1.476 & 0.003 & 0.993 \\
\hline
\end{tabular}

a, b, c mean values on the same rows not sharing a superscript are significantly different. "Control $=$ Basal diet + No additive. $\mathbf{P}+\mathrm{CH}=$ Peppermint + Chamomile. $\mathbf{P}+\mathrm{Y}=$ Peppermint + Yeast. $\mathrm{CH}+\mathrm{Y}=$ Chamomile + Yeast. $\mathbf{P}+\mathrm{Y}+\mathbf{C H}=$ Peppermint + Yeast + Chamomile.

\section{Serum biochemistry}

Among the measured serum biochemical parameters, the cholesterol was decreased in birds that were fed on diets containing the mixture of peppermint and chamomile followed by those offered diets that contained the mixture of peppermint, chamomile and yeast (Table 5). The higher cholesterol level in the serum was recorded on birds that consumed the diet that was supplemented by the mixture of chamomile and yeast compared to the other experimental groups. The combination of medical plants and yeast cell wall in the current study had hypocholestrolic effect. Lipase activity of both pancreas and gastric origin could be reduced by dietary herbal plants, thus reducing the fat digestibility in the gastrointestinal tract (6). Furthermore, herbal plants may inhibit fat metabolism thereby interfering with the cholesterol solubility in the gastrointestinal tract decreasing its absorption and increasing the excretion of bile acid in the feces (29). The hypocholestrolic effect of chamomile was also reported by $(3,16)$.

Table 4. Effect of different treatments on the relative internal organs weights $(\mathrm{g} / 100 \mathrm{~g} \mathrm{BW})$ of broilers at $d 24$ of age.

\begin{tabular}{|lcccccc|}
\hline Treatments $^{*}$ & Liver & Heart & Spleen & Gizzard & Small Intestine & $\begin{array}{c}\text { Bursa of } \\
\text { Fabricius }\end{array}$ \\
\hline Control & $\mathbf{3 . 1 1}$ & $\mathbf{0 . 7 7 7}$ & $\mathbf{0 . 1 0 4}$ & $\mathbf{3 . 7 2 6}$ & $\mathbf{7 . 0 7 8}$ & $\mathbf{0 . 1 4 7}$ \\
P+CH & $\mathbf{3 . 0 6}$ & $\mathbf{0 . 6 0 0}$ & $\mathbf{0 . 0 7 7}$ & $\mathbf{4 . 2 0 9}$ & $\mathbf{7 . 0 5 5}$ & $\mathbf{0 . 1 5 1}$ \\
P+Y & 4.04 & $\mathbf{1 . 5 2 0}$ & $\mathbf{0 . 1 6 9}$ & $\mathbf{5 . 5 6 1}$ & $\mathbf{1 2 . 0 8 9}$ & $\mathbf{0 . 3 6 8}$ \\
CH+Y & $\mathbf{2 . 7 2}$ & $\mathbf{0 . 5 8 0}$ & $\mathbf{0 . 0 9 1}$ & $\mathbf{5 . 2 5 0}$ & $\mathbf{6 . 7 7 1}$ & $\mathbf{0 . 1 7 5}$ \\
P+Y+CH & $\mathbf{2 . 7 6}$ & $\mathbf{0 . 5 7 8}$ & $\mathbf{0 . 0 9 0}$ & $\mathbf{3 . 6 9 6}$ & $\mathbf{7 . 4 9 6}$ & $\mathbf{0 . 1 5 5}$ \\
Pooled SEM & $\mathbf{0 . 2 0 5}$ & $\mathbf{0 . 1 3 2}$ & $\mathbf{0 . 0 1 6}$ & $\mathbf{0 . 2 9 4}$ & $\mathbf{0 . 7 1 9}$ & $\mathbf{0 . 0 3 3}$ \\
P-Value & $\mathbf{0 . 2 4 7}$ & $\mathbf{0 . 0 8 9}$ & $\mathbf{0 . 4 1 9}$ & $\mathbf{0 . 1 2 0}$ & $\mathbf{0 . 0 7 8}$ & $\mathbf{0 . 1 5 4}$ \\
\hline
\end{tabular}

${ }^{*}$ Control $=$ Basal diet + No additive. $\mathbf{P}+\mathrm{CH}=$ Peppermint + Chamomile. $\mathbf{P}+\mathrm{Y}=$ Peppermint + Yeast. $\mathrm{CH}+\mathrm{Y}=$ Chamomile + Yeast. $\mathrm{P}+\mathrm{Y}+\mathrm{CH}=$ Peppermint + Yeast + Chamomile 
Table 5. Effect of different treatments on serum biochemical parameters of broilers at d 24 of age.

\begin{tabular}{|c|c|c|c|c|c|c|}
\hline Treatments $^{*}$ & $\begin{array}{c}\text { Cholesterol } \\
(\mathrm{mg} / \mathrm{dl})\end{array}$ & ALT (ul) & AST (ul) & $\begin{array}{c}\text { Total } \\
\text { Protein } \\
\text { (g/dl) }\end{array}$ & $\begin{array}{l}\text { Albumen } \\
\text { (g/dl) }\end{array}$ & $\begin{array}{c}\text { Globulin } \\
\text { (g/dl) }\end{array}$ \\
\hline Control & $91^{a b}$ & 2.43 & 158 & 2.533 & 1.058 & 1.475 \\
\hline $\mathrm{P}+\mathrm{CH}$ & $\mathbf{7 8}^{\mathrm{b}}$ & 1.93 & 146 & 2.178 & 0.838 & 1.340 \\
\hline $\mathbf{P}+\mathbf{Y}$ & $9^{a b}$ & 1.73 & 164 & 2.663 & 1.010 & 1.653 \\
\hline $\mathbf{C H}+\mathrm{Y}$ & $107^{\mathrm{a}}$ & 1.95 & 174 & 2.598 & 1.035 & 1.563 \\
\hline $\mathrm{P}+\mathrm{Y}+\mathrm{CH}$ & $80^{b}$ & 2.45 & 130 & 1.836 & 0.766 & 1.069 \\
\hline Pooled SEM & 3.627 & 0.129 & 5.900 & 0.121 & 0.047 & 0.077 \\
\hline P-Value & 0.0399 & 0.2914 & 0.1543 & 0.1475 & 0.1882 & 0.1226 \\
\hline
\end{tabular}

a, b - Mean values on the same column not sharing a superscript are significantly different at $(\mathbf{P}<0.05)$.

*Control $=$ Basal diet + No additive. $\mathbf{P}+\mathbf{C H}=$ Peppermint + Chamomile. $\mathbf{P}+\mathbf{Y}=$ Peppermint $+\mathbf{Y}$ east. $\mathbf{C H}+\mathbf{Y}=$ Chamomile + Yeast. $\mathbf{P}+\mathrm{Y}+\mathrm{CH}=$ Peppermint + Yeast + Chamomile $; \mathrm{ALT}=$ Alanine transaminase, and AST $=$ Aspartate aminotransferase (AST).

Jejunum and bursal histomorphology

Villi were significantly longer in all experimental groups compared to the control (Table 6). Crypt depth significantly decreased in birds that were fed diets contained the mixture of peppermint and yeast cell wall compared to the control group followed by those on diets supplemented with the mixture of chamomile and yeast. Villi height to crypt depth ratio increased by dietary treatment, however it was only significant in birds that were fed diets contained the mixture of peppermint and yeast compared to the control group. Villi tip width, base width and the apparent villi surface area were significantly decreased in all experimental groups compared to the control. Jejunum muscle thickness increased in birds on diets containing the mixture of chamomile and yeast cell wall, however that of birds on diets containing the mixture of peppermint and yeast was significantly the less compared to the control and other experimental groups. In this study there was an improvement in the jejunal histomorphology of broiler chickens due to the consumption of a mixture of chamomile, peppermint and yeast cell wall. This may be attributed to the presence of bioactive compounds in the medical plants that could improve the gut health and intestinal morphology. Improving the jejunal morphology of birds including villus height or villus height-to-crypt depth ratio may point out to the efficient digestion, better absorptive capacity which may lead to the better nutrient uptake and utilization and finally better performance. These findings were in line with those of $(15,25)$ when phytogenic additives were included in the broiler diets. Similar findings have also been found by (9) when peppermint was included to the broiler diets. Furthermore (16) have also obtained the similar findings by dietary chamomile. In addition to the effect of medical plants, yeast cell wall may also involve in the development of the intestinal morphology thereby enhancing the production of short chain organic acids that may induce as a result of the fermentation of dietary prebiotic by the bacterial community in the intestine. The short chain organic acids which are by products of bacterial fermentation stimulate the proliferation of epithelial cells of the bowel (12). In addition, some bacteria may recognize binding sites on the prebiotic as if they were from the intestinal mucosa and the colonization of the intestine by pathogenic bacteria is thus reduced, therefore besides a lower infection incidence; there is an increase in the absorption of available nutrients, a mechanism that directly affects the recovery of intestinal mucosa, increasing villi height (14). 
5. Beski, S.S.M. 2018.Physiological and immunological responses of Japanese quails to oleobiotic. Iraqi J. Agric. Sci., 49(2):291-299

6. Deng, Z, B. Teo, X Li, J. He, Y. Cheni, and F Chu. 1998. Effect of tea on blood glucose, blood lipid and antioxidants activity in old rats. J. of tea-Sci, 18: 1-74

7. Froebel, L. K., S. Jalukar, T. A. Lavergne, J. T. Lee, and T. Duong. 2019. Administration of dietary prebiotics improves growth performance and reduces pathogen colonization in broiler chickens. Poult. Sci., 98: 6668-6676

8. Gibson, G. R., R. Hutkins, M. E. Sanders, S. L. Prescott, R. A. Reimer, S. J. Salminen, K. Scott, C. Stanton, K. S. Swanson, P. D. Cani, K. Verbeke, and G. Reid. 2017. Expert consensus document: The International Scientific Association for Probiotics and Prebiotics (ISAPP) consensus statement on the definition and scope of prebiotics. Nat. Rev. Gastroenterol. Hepatol. 14:491

9. Hasan, H. I., S. A. M'Sadeq. 2020. Effect of peppermint supplementation as powder or extract on broiler performance, serum biochemical content and gut health under $\mathrm{E}$ coli challenge. Iraqi J. Agric. Sci.,, 51(1):299310

10. Hoffman-Pennesi, D., and C. Wu. 2010. The effect of thymol and thyme oil feed supplementation on growth performance, serum antioxidant levels, and cecal Salmonella population in broilers. J. Appl. Poult. Res. 19:432-443

11. Huyghebaert, G., R. Ducatelle, and F. Van Immerseel. 2011. An update on alternatives to antimicrobial growth promoters for broilers. Vet. J. 187:182-188

12. Ichikawa, H., T. Kuroiwa, A. Inagaki, R. Shineha, Nishihira, S. Satomi and T. Sakata, 1999. Probiotic bacteria stimulate gut epithelial cell proliferation in rat. Digestive Dis. and Sci., 44: 2119-2123

13. Iji, P. A., A. Saki, and D. R. Tivey. 2001. Body and intestinal growth of broiler chicks on a commercial starter diet. 1. Intestinal weight and mucosal development. Br. Poult. Sci. 42: 505-13

14. Iji, P.A. and D.R. Tivey, 1998. Natural and synthetic oligosaccarides in broiler chicken diets. Word Poult. Sci. J., 54: 129-143
15. Khattak, F, A. Ronchi, P. Castelli, and N. Sparks. 2013. Effects of natural blend of essential oil on growth performance, blood biochemistry, cecal morphology, and carcass quality of broiler chickens. Poult. Sci., 93(1): 132-137

16. Khishtan, A.T.M and S.S.M. Beski. 2020. Delivery route of chamomile on the growth and subsequent physiology of broiler chickens under E. coli challenge. Iraqi J. Agric. Sci., 51(4):1058-1073

17. Lee, K-W, H. Everts, H. Kappert, M. Frehner, R. Losa, and A. Beynen. 2003. Effects of dietary essential oil components on growth performance, digestive enzymes and lipid metabolism in female broiler chickens. Br. Poult. Sci., 44(3): 450-457

18. Mahmmod, Z. A. 2013.The effect of chamomile plant (Matricaria chamomile L.) as feed additives on productive performance, carcass characteristics and immunity response of broiler. Int. J. Poult. Sci, 12(2): 111-116

19. McCrea, B, K. Macklin, R. Norton, J .Hess, and S. Bilgili 2005. Recovery of Campylobacter jejuni front broiler house samples during four consecutive flocks: Dendrogram. In Poultry Science. Poultry Science Assoc INC 1111 N DUNLAP AVE, Savoy, IL 61874-9604 USA

20. Nahashon, S., H. Nakaue, and L. Mirosh. 1994. Production variables and nutrient retention in Single Comb White Leghorn laying pullets fed diets supplemented with direct-fed microbials. Poult. Sci. 73:16991711.

21. Nematollah Asadi, Seyed Davood Husseini, Mohammad-Taghi Tohidian, Nargess Abdali, Amir Mimandipoure, Mahmoud Rafieian-Kopaei, and Mahmoud Bahmani. 2017. Performance of Broilers Supplemented With Peppermint (Mentha piperita L.) Powder. J Evid Based Complementary Altern Med. 22(4): 703-706

22. Ocak, N., G. Erener, F. Burak Ak, M. Sungu, A. Altop, and A. Ozmen. 2008. Performance of broilers fed diets supplemented with dry peppermint (Mentha piperita L.) or thyme (Thymus vulgaris L.) leaves as growth promoter source. Czech J. Anim. Sci. 53:169-175

23. Panda, H. 2005. Aromatic Plants Cultivation, Processing And Uses: How to 
Start a Successful Aromatic Plants Business, How to Start Aromatic plants cultivation Industry in India, How to Start Aromatic Plants farm? How to Start Aromatic plants Production Business, Indian aromatic Plant, List of Aromatic Plants and their Uses. Asia Pacific Business Press Inc

24. Patterson, J., and K. Burkholder. 2003. Application of prebiotics and probiotics in poultry production. Poult. Sci. 82:627-631

25. Reisinger, N, T Steiner, S. Nitsch, G. Schatzmayr, and T. Applegate. 2011. Effects of a blend of essential oils on broiler performance and intestinal morphology during coccidial vaccine exposure. J. Appl. Poult. Res., 20(3): 272-283

26. Salianeh, N., M. Shirzad, and S. Seifi. 2011. Performance and antibody response of broiler chickens fed diets containing probiotic and prebiotic. J. Appl. Anim. Res. 39:65-67
27. Torres-Rodriguez, A., S. E. Higgins, J. L. S. Vicente, A. D. Wolfenden, G. GaonaRamirez, J. T. Barton, G. Tellez, A. M. Donoghue, and B. M. Hargis. 2007. Effect of lactose as a prebiotic on turkey body weight under commercial conditions. J. Appl. Poult. Res. 16:635-641

28. Yalçin, S., S. Yalçin, K. Uzunoğlu, H. M. Duyum, and Ö. Eltan. 2012. Effects of dietary yeast autolysate (Saccharomyces cerevisiae) and black cumin seed (Nigella sativa L.) on performance, egg traits, some blood characteristics and antibody production of laying hens. Livest. Sci. 145:13-20

29. Yang, T. T. and M. W. Koo. 1999. Chinese green tea lowers cholesterol level through an increase in fecal lipid excretion. Life Sci., 66(5): 411-423. 